\title{
Kajian Budidaya Tanaman Kelapa Sawit (Elaeis Guineensis Jacq.) di Kabupaten Pulang Pisau Provinsi Kalimantan Tengah
}

\section{Study on Cultivation of Oil Palm (Elaeis Guineensis Jacq.) in Pulang Pisau Regency, Central Kalimantan Province}

Flora Chisyashita

Magister Manajemen, Pasca Sarjana, Universitas Palangka Raya

\section{ARTICLE INFO}

Article history:

DOI:

$\underline{10.30595 / p s p f s . v 2 i .186}$

Submitted:

July 29, 2021

Accepted:

Sept 10, 2021

Published:

Nov 10, 2021

\section{Keywords:}

Cultivation Techniques Palm, In the Districk of Returning Knives

\begin{abstract}
The objective of this research was to study of cultivation techniques palm oil independent farmers and social aspects to palm oil production. This research has conducted in In The Districk of Returning Knives from January 2021 until March 2021. The research was conducted using survey and the sampling used for this research purposive sampling. Consist of 60 sample, based on $10 \%$ level of representation. 30 sample drawn from Pangkoh Village and 30 sample drawn from Mandomai Village. The parameters studied were, land clearing, the origin of the seeds, size of planting holes, seed age, plant spacing, pruning, control of weeds and fertilization. The results show that the average production palm oil of farmers are still very low at less than $50 \%$ when compared to the average production of palm oil of PPKS Palangka Raya on mineral lands in general. The low production of palm oil cultivation techniques of farmers due to conducted as seed origin, plant spacing, pattern spacing, the size of the planting hole, transplanting seedlings into the ground, fertilizing, are still quite low level of the appropriate palm oil cultivation techniques application in the field.
\end{abstract}

This work is licensed under a Creative Commons Attribution 4.0 International License.

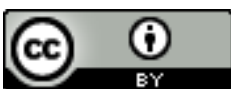

Corresponding Author:

Flora Chisyashita

Magister Manajemen, Pasca Sarjana, Universitas Palangka Raya

Email: florachisy@gmail.com

\section{PENDAHULUAN}

Kelapa sawit (Elaeis guineensis Jacq.) menghasilkan produk yang dapat dipasarkan secara Internasional salah satunya Crude Palm Oil (CPO), dimana CPO dapat menyumbang devisa bagi negara melalui ekspor nonmigas tanaman perkebunan. Perkembangan usaha dan investasi kelapa sawit terus mengalami pertumbuhan sehingga terjadi peningkatan luas areal perkebunan kelapa sawit yang dilakukan masyarakat secara swadaya.

Luas areal tanaman kelapa sawit di Provinsi Kalimantan Tengah pada tahun 2021 mengalami peningkatan yaitu pada tahun 2019, luas areal pertanaman kelapa sawit mencapai 1.922 .083 hektar (ha) dengan total produksi sebesar 5.932.308 ton CPO. Pada tahun 2020 luas areal pertanaman kelapa sawit mencapai 2.018.660 ha dengan total produksi sebesar 6.293.542 ton CPO dan pada tahun 2021 luas areal pertanaman kelapa sawit mencapai 2.049.790 ha dengan total produksi 6.932.572 ton CPO (Badan Pusat Statistik Provinsi Kalimantan Tengah, 2021). 
Salah satu daerah pengembangan perkebunan kelapa sawit yaitu di Kabupaten Pulang Pisau Desa Pangkoh dan Desa Mandomai yang terdapat pada berbagai lahan mineral yang bergelombang. Kendala yang dihadapi pelaksanaan teknik budidaya yaitu asal bibit, pemeliharaan tanaman, pengendalian gulma, hama penyakit dan pemupukan. Untuk itu penerapan teknologi budidaya memerlukan perencanaan, pengelolaan, menajemen sumber daya manusia dan informasi.

Beberapa faktor teknik budidaya yang mempengaruhi produksi kelapa sawit antara lain: pembibitan kelapa sawit, pembukaan lahan, penanaman dan perawatan tanaman yang benar. Perawatan tanaman meliputi: penyulaman, penanaman tanaman penutup tanah (Cover Crop), pemberantasan gulma, penunasan, pemupukan, kastrasi, penyerbukan buatan, pengendalian hama dan penyakit (Fauzi dkk., 2008).

Tujuan dari penelitian adalah untuk mengetahui pelaksanaan teknik budidaya tanaman kelapa sawit yang dilaksanakan secara swadaya di Kabupaten Pulang Pisau Provinsi Kalimantan Tengah.

\section{BAHAN DAN METODE}

Penelitian ini telah dilaksanakan di Kabupaten Pulang Pisau Provinsi Kalimantan Tengah dari bulan Januari sampai Maret 2021. Penelitian ini menggunakan metode survey. Pengambilan sampel untuk petani dilakukan secara sengaja (purposive sampling) dengan pertimbangan luas lahan minimal 2 ha, umur tanaman kelapa sawit 3 tahun setelah tanam. Sampel yang diambil untuk penelitian didasarkan pada tingkat keterwakilan $10 \%$ dari jumlah populasi 604 petani.

Data yang telah diambil ditabulasi berdasarkan kelompok data. Kelompok data ini mencakup data karakteristik petani sampel, Data yang telah diperoleh selanjutnya dianalisis secara deskriptif dengan membuat tabulasi data dalam bentuk tabel dan grafik, selanjutnya data dihimpun berdasarkan subjeknya.

\section{HASIL dan PEMBAHASAN}

\section{Luas dan status kepemilikan lahan}

Lahan bagi petani merupakan faktor produksi yang sangat penting selain sumberdaya ekonomi dan sumberdaya manusia. Sumberdaya ekonomi dan manusia belum sempurna apabila tidak menguasai sumberdaya alam berupa lahan bagi usaha tani, petani menggantungkan semua harapan kepada apa yang dihasilkan oleh lahan tersebut.

Pada Tabel 1 dilihat bahwa besar kecilnya lahan mempengaruhi pendapatan yang diperoleh dari produk yang dihasilkan, kepemilikan lahan petani dari kedua desa beragam, status lahan pribadi dengan luas pemilikan lahan lebih dominan 2 ha diperoleh $46,67 \%$, 3 ha diperoleh $31,67 \%$, dan luas lahan 4 ha mencapai $15 \%$ sementara luas lahan 5 ha hanya diperoleh 5\%. Luas lahan yang diberikan pemerintah yaitu 3 ha, 2 ha lahan yang dikelola untuk perkebunan kelapa sawit dan yang 1 ha dibagi menjadi 3/4 untuk lahan tanaman pangan dan 1/4 untuk pekarangan. Hal ini menunjukkan bahwa lahan yang dimiliki memungkinkan bagi petani melakukan suatu usaha perkebunan kelapa sawit. Dari luas lahan terbanyak dari kedua desa diperoleh sebanyak 2 ha yaitu $46,67 \%$ luas lahan tersebut dapat dimanfaatkan sebaik-baiknya, jika petani melakukan perawatan tanaman kelapa sawit dengan baik.

Tabel 1. Distribusi Petani Sampel Berdasarkan Luas Kepemilikan Lahan

\begin{tabular}{|c|c|c|c|c|c|c|}
\hline \multirow{3}{*}{$\begin{array}{l}\text { Luas Kepemilikan } \\
\text { (ha) }\end{array}$} & \multicolumn{4}{|c|}{ Desa } & \multirow{3}{*}{$\begin{array}{l}\text { Jumlah } \\
\text { (jiwa) }\end{array}$} & \multirow{3}{*}{ Persentase (\%) } \\
\hline & \multicolumn{2}{|c|}{ Pangkoh } & \multicolumn{2}{|c|}{ Mandomai } & & \\
\hline & Jumlah & Persentase & Jumlah & Persentase & & \\
\hline 1 & 0 & 0 & 0 & 0 & 0 & 0 \\
\hline 2 & 13 & 43,33 & 15 & 50,00 & 28 & 46,67 \\
\hline 3 & 9 & 30,00 & 10 & 33,33 & 19 & 31,67 \\
\hline 4 & 6 & 20,00 & 3 & 10,00 & 9 & 15,00 \\
\hline 5 & 2 & 6,67 & 1 & 3,33 & 3 & 5,00 \\
\hline Jumlah & 30 & 100 & 30 & 100 & 60 & 100 \\
\hline
\end{tabular}

Semakin luas lahan petani kelapa sawit belum tentu dapat meningkatkan produksi tanaman kelapa sawit, jika tidak dilakukan perawatan tanaman yang baik. Luas lahan diartikan sebagai tanah yang disiapkan untuk diusahakan usaha tani misalnya perkebunan, tegal, pekarangan dan ukuran luas lahan secara tradisional perlu dipahami agar dapat ditransformasi ke ukuran luas lahan yang dinyatakan dengan hektar (Soekartawi, 1995).

\section{Karakteristik Eksternal Petani Sampel}

Karakteristik eksternal petani pada Tabel 2 dilihat bahwa berdasarkan jawaban keseluruhan responden intensitas penyuluhan tentang budidaya kelapa sawit belum pernah ada, sehingga petani sulit memahami budidaya kelapa sawit terutama tentang pemeliharaan tanaman terutama terhadap pemupukan, karena 
ketersediaan penyuluh yang terbatas, petani sangat mengharapkan adanya penyuluh yang bisa membantu dalam meningkatkan produktivitas kelapa sawit.

Tabel 2. Karakteristik eksternal petani kalapa sawit rakyat

\begin{tabular}{lll}
\hline No. & Karakteristik Eksternal & Keterangan \\
\hline 1 & Intensitas penyuluh & $\begin{array}{l}\text { Belum ada penyuluhan tentang } \\
\text { budidaya kelapa sawit }\end{array}$ \\
& & Rendah \\
3 & Pemahaman petani tentang budidaya sawit & Terbatas \\
4 & Jumlah sumber informasi & Tersedia dalam jumlah sedikit \\
\hline
\end{tabular}

Berdasarkan hasil interview dalam bentuk wawancara pemahaman petani mengenai budidaya masih rendah. Ketersediaan sarana produksi untuk meningkatkan produktivitas kebun kelapa sawit seperti pupuk, pestisida banyak tersedia namun kemampuan petani untuk membeli sangat rendah karena harga pupuk mahal dan tidak dapat dijangkau oleh petani. Menurut Edwina dkk. (2004) mayoritas petani (90\%) tidak mampu membeli pupuk, harapan petani untuk memperoleh pupuk dengan harga yang terjangkau dan berkualitas untuk meningkatkan produksi kelapa sawit, maupun penyuluhan dan temuan inovasi pengolahan pupuk dari bahan baku lokal yang tersedia dengan teknologi pengolahan sesuai kemampuan petani.

\section{Persiapan Pembukaan Lahan}

Persiapan pembukaan lahan merupakan kegiatan awal yang dilakukan sebelum penanaman tanaman kelapa sawit. Lahan yang digunakan oleh petani sampel di kedua Desa pada umumnya adalah areal hutan dan semak belukar. Berikut ini merupakan tahapan persiapan pembukaan lahan tanaman kelapa sawit yang dilakukan pada perkebunan petani swadaya di Kabupaten Pulang Piau yang disajikan dalam bentuk Tabel 3.

Tabel 3. Persiapan Pembukaan Lahan Tanaman Kepala Sawit

\begin{tabular}{|c|c|c|c|}
\hline \multirow{2}{*}{ No. } & \multirow{2}{*}{$\begin{array}{l}\text { Persiapan } \\
\text { Lahan }\end{array}$} & \multicolumn{2}{|c|}{ Desa } \\
\hline & & Pangkoh & Mandomai \\
\hline 1 & Kondisi lahan & $\begin{array}{l}\text { Hutan dan semak belukar, } \\
\text { berbukit }\end{array}$ & $\begin{array}{l}\text { Hutan dan semak belukar, } \\
\text { berbukit }\end{array}$ \\
\hline 2 & Teknik pembukaan lahan & Mekanis tanpa bakar & Mekanis tanpa bakar \\
\hline
\end{tabular}

Berdasarkan Tabel 3 diketahui bahwa persiapan pembukaan lahan yang dilakukan di Kecamatan Lubuk Dalam yaitu dengan cara mekanis tanpa pembakaran. Hal ini dikarenakan proses persiapan pembukaan lahan berpedoman terhadap konsep pengelolaan lingkungan secara berkelanjutan dan peraturan pemerintah No. 150 tahun 2000 menjelaskan bahwa tentang pengendalian kerusakan tanah untuk produksi biomassa memperoleh manfaat yang optimal bagi kelestarian lingkungan.

Gangguan yang ditimbulkan oleh kebakaran hutan dan lahan tersebut berupa perubahan ekosistem hutan, menurunnya keanekaragaman hayati, rusaknya kesuburan tanah. Pedoman tersebut menyarankan sebaiknya pembukaan lahan tanpa adanya pembakaran, karena akan merusak tanah dan kelestarian lingkungan, metode pembukaan lahan hutan dapat dilakukan dengan cara menebang dan menumbangkan vegetasi lahan yang lama menggunakan mesin tebang (chainsaw) dan buldoser (Hakim, 2007).

\section{Persiapan Bahan Tanaman Pembibitan}

Pembibitan merupakan proses mengembangkan benih atau kecambah menjadi bibit yang siap untuk ditanam. Pemilihan bibit dan pemahaman terhadap sifat dan karakteristik bibit kelapa sawit merupakan faktor penting terhadap budidaya kelapa sawit.

Tabel 4. Distribusi petani sampel berdasarkan varietas yang ditanam

\begin{tabular}{|c|c|c|c|c|c|c|c|}
\hline \multirow{3}{*}{ No } & \multirow{3}{*}{$\begin{array}{l}\text { Varietas } \\
\text { Tanaman }\end{array}$} & \multicolumn{4}{|c|}{ Desa } & \multirow{3}{*}{$\begin{array}{l}\text { Jumlah } \\
\text { (jiwa) }\end{array}$} & \multirow{3}{*}{$\begin{array}{c}\text { Persentase } \\
\quad(\%)\end{array}$} \\
\hline & & \multicolumn{2}{|c|}{ Pangkoh } & \multicolumn{2}{|c|}{ Mandomai } & & \\
\hline & & $\begin{array}{c}\text { Jumlah } \\
\text { (jiwa) }\end{array}$ & $\begin{array}{c}\text { Persentase } \\
(\%)\end{array}$ & $\begin{array}{c}\text { Jumlah } \\
\text { (jiwa) }\end{array}$ & $\begin{array}{c}\text { Persentase } \\
(\%)\end{array}$ & & \\
\hline 1 & Marihat & 12 & 40,00 & 10 & 33,33 & 22 & 36,67 \\
\hline 2 & Topaz & 10 & 33,33 & 9 & 30,00 & 19 & 31,67 \\
\hline \multirow[t]{2}{*}{3} & Tidak jelas & 8 & 26,67 & 11 & 36,67 & 19 & 31,67 \\
\hline & Jumlah & 30 & 100 & 30 & 100 & 60 & 100 \\
\hline
\end{tabular}


Pada Tabel 4 petani sampel dari kedua desa menunjukkan penggunaan varietas tanam yang tidak jelas asal usulnya sebesar 31,67\% sebab informasi mengenai asal bibit Marihat tidak disertai bukti sertifikat tidak dapat dipertanggung jawabkan keaslian bibit/kecambah yang digunakan sebagai bahan tanam kelapa sawit.

\section{Penanaman}

Tahap penanaman kelapa sawit yang perlu diperhatikan yaitu pembuatan lubang tanam, umur bibit siap tanam, jarak tanam dan pola penanaman, tahap ini sangat berpengaruh terhadap pertumbuhan dan perkembangan tanaman kelapa sawit.

\section{Ukuran Lubang Tanam}

Lubang tanam berfungsi sebagai tempat media tumbuh tanaman pada awal pertumbuhan serta memudahkan peresapan pupuk ke dalam tanah. Analisa langsung yang dilakukan terhadap distribusi sampel berdasarkan ukuran lubang tanam terdapat pada Tabel 5.

Tabel 5. Distribusi petani sampel berdasarkan ukuran lubang tanam

\begin{tabular}{|c|c|c|c|c|c|c|c|}
\hline \multirow{3}{*}{ No } & \multirow{3}{*}{$\begin{array}{l}\text { Ukuran } \\
\text { Lubang } \\
\text { Tanam }\end{array}$} & \multicolumn{4}{|c|}{ Desa } & \multirow{3}{*}{$\begin{array}{l}\text { Jumlah } \\
\text { (jiwa) }\end{array}$} & \multirow{3}{*}{$\begin{array}{c}\text { Persentase } \\
(\%)\end{array}$} \\
\hline & & \multicolumn{2}{|c|}{ Pangkoh } & \multicolumn{2}{|c|}{ Mandomai } & & \\
\hline & & $\begin{array}{l}\text { Jumlah } \\
\text { (jiwa) }\end{array}$ & $\begin{array}{c}\text { Persentase } \\
(\%)\end{array}$ & $\begin{array}{l}\text { Jumlah } \\
\text { (jiwa) }\end{array}$ & $\begin{array}{c}\text { Persentase } \\
(\%)\end{array}$ & & \\
\hline 1 & $60 \times 60 \times 60$ & 6 & 20,00 & 9 & 30,00 & 15 & 25,00 \\
\hline 2 & $50 \times 50 \times 30$ & 15 & 50,00 & 11 & 36,60 & 26 & 43,33 \\
\hline 3 & $60 \times 60 \times 40$ & 4 & 13,30 & 2 & 6,66 & 6 & 10,00 \\
\hline 4 & $50 \times 50 \times 50$ & 5 & 16,60 & 8 & 26,60 & 13 & 21,66 \\
\hline 5 & $\begin{array}{l}\text { Tanpa } \\
\text { ukuran }\end{array}$ & - & - & - & - & - & - \\
\hline & Jumlah & 30 & 100 & 30 & 100 & 60 & 100 \\
\hline
\end{tabular}

Pada Tabel 5 ukuran lubang tanam kelapa sawit pada petani sampel di kedua desa mayoritas menggunakan lubang tanam $50 \mathrm{~cm}$ × $50 \mathrm{~cm}$ × $30 \mathrm{~cm}$ mencapai 43,33\%, selanjutnya ukuran lubang tanam yang memenuhi standar $60 \mathrm{~cm} \times 60 \mathrm{~cm}$ x $60 \mathrm{~cm}$ dua desa diperoleh sebanyak 25\% dengan standar ukuran lubang tanam. Jenis tanah yang dominan pada areal tersebut yaitu jenis tanah mineral dan bergelombang, ukuran lubang tanam yang tidak sesuai mempengaruhi perkembangan akar tanaman dan rentannya resiko kemiringan terhadap tanaman sehingga dapat mengurangi produksi kelapa sawit. Ukuran lubang tanam yang direkomendasikan adalah $60 \mathrm{~cm}$ x $60 \mathrm{~cm}$ x $60 \mathrm{~cm}$ dapat memudahkan peresapan pupuk kedalam tanah, perkembangan akar lebih optimal.

\section{Umur Bibit}

Umur penanaman bibit mempengaruhi pertumbuhan dan produksi tanaman kelapa sawit, untuk itu perlu diperhatikan umur bibit harus tepat waktu saat penanaman di lahan.

Tabel 6. Distribusi petani sampel berdasarkan umur bibit pindah tanam

\begin{tabular}{|c|c|c|c|c|c|c|c|}
\hline \multirow{3}{*}{ No } & \multirow{3}{*}{$\begin{array}{l}\text { Umur Bibit } \\
\text { (bulan) }\end{array}$} & \multicolumn{4}{|c|}{ Desa } & \multirow{3}{*}{$\begin{array}{c}\text { Jumlah } \\
\text { (jiwa) }\end{array}$} & \multirow{3}{*}{$\begin{array}{c}\text { Persentase } \\
(\%)\end{array}$} \\
\hline & & \multicolumn{2}{|c|}{ Pangkoh } & \multicolumn{2}{|c|}{ Mandomai } & & \\
\hline & & $\begin{array}{c}\text { Jumlah } \\
\text { (jiwa) }\end{array}$ & $\begin{array}{c}\text { Persentase } \\
(\%)\end{array}$ & $\begin{array}{c}\text { Jumlah } \\
\text { (jiwa) }\end{array}$ & $\begin{array}{c}\text { Persentase } \\
(\%)\end{array}$ & & \\
\hline 1 & $<12$ & 19 & 63,33 & 16 & 53,33 & 35 & 58,33 \\
\hline 2 & $12-14$ & 7 & 23,33 & 9 & 30,00 & 16 & 26,67 \\
\hline \multirow[t]{2}{*}{3} & $>14$ & 4 & 13,33 & 5 & 16,66 & 9 & 15,00 \\
\hline & Jumlah & 30 & 100 & 30 & 100 & 60 & 100 \\
\hline
\end{tabular}

Pemindahan bibit tanaman kelapa sawit pada umur kurang dari 12 bulan dapat menyebabkan tanaman menjadi stres, layu, mudah terserang hama serta rentan mengalami kematian, bibit yang baik dianjurkan dalam melakukan transplanting pada umur 12-14 bulan serta penggunaan bibit di atas 20 bulan tanaman rentan mengalami stagnasi produksi menjadi lambat (Fauzi dkk., 2008).

\section{Jarak Tanam}

Tanaman kelapa sawit merupakan tanaman C-4 dimana tumbuhan ini dapat melakukan fotosintesis yang lebih efisien pada intensitas cahaya matahari tinggi, intensitas cahaya matahari yang tinggi dapat mendorong pertumbuhan vegetatif, pembentukan bunga dan buah pada tanaman. Pengaturan jarak tanam yang belum sesuai dapat menyebabkan perolehan persaingan cahaya matahari, dampak tersebut tanaman pada umumnya tidak normal serta berpengaruh terhadap pembentukan bunga dan buah tanaman. 
Tabel 7. Distribusi petani sampel berdasarkan jarak tanam

\begin{tabular}{cccccccc}
\hline & & \multicolumn{9}{c}{ Mandomai } & & \multicolumn{2}{c}{$\begin{array}{c}\text { Jumlah } \\
\text { No }\end{array}$} & Jarak Tanam & \multicolumn{2}{c}{ Pangkoh } & \multicolumn{2}{c}{$\begin{array}{c}\text { Persentase } \\
(\%)\end{array}$} \\
\cline { 3 - 6 } & & $\begin{array}{c}\text { Jumlah } \\
\text { (jiwa) }\end{array}$ & $\begin{array}{c}\text { Persentase } \\
(\%)\end{array}$ & $\begin{array}{c}\text { Jumlah } \\
\text { (jiwa) }\end{array}$ & $\begin{array}{c}\text { Persentase } \\
(\%)\end{array}$ & & \\
\hline 1 & $8 \times 8$ & 6 & 20,00 & 12 & 40,00 & 18 & 30,00 \\
2 & $8 \times 9$ & 14 & 46,67 & 2 & 6,67 & 16 & 26,67 \\
3 & $9 \times 9$ & 10 & 33,33 & 16 & 53,33 & 26 & 43,33 \\
\hline & Jumlah & 30 & 100 & 30 & 100 & 60 & 100 \\
\hline
\end{tabular}

Pola Jarak Tanam

Tabel 8. Distribusi Petani Sampel Berdasarkan Pola Jarak Tanam

\begin{tabular}{|c|c|c|c|c|c|c|c|}
\hline \multirow{3}{*}{ No } & \multirow{3}{*}{ Pola Jarak Tanam - } & \multicolumn{4}{|c|}{ Desa } & \multirow{3}{*}{$\begin{array}{l}\text { Jumlah } \\
\text { (jiwa) }\end{array}$} & \multirow{3}{*}{$\begin{array}{c}\text { Persentase } \\
(\%)\end{array}$} \\
\hline & & \multicolumn{2}{|c|}{ Pangkoh } & \multicolumn{2}{|c|}{ Mandomai } & & \\
\hline & & $\begin{array}{c}\text { Jumlah } \\
\text { (jiwa) }\end{array}$ & $\begin{array}{c}\text { Persentase } \\
(\%)\end{array}$ & $\begin{array}{l}\text { Jumlah } \\
\text { (jiwa) }\end{array}$ & $\begin{array}{c}\text { Persentase } \\
(\%)\end{array}$ & & \\
\hline 1 & $\begin{array}{l}\text { Segi tiga sama } \\
\text { sisi }\end{array}$ & 7 & 23,33 & 11 & 36,67 & 18 & 30,00 \\
\hline \multirow[t]{2}{*}{2} & Segi empat & 23 & 76,66 & 19 & 63,33 & 42 & 70,00 \\
\hline & Jumlah & 30 & 100 & 30 & 100 & 60 & 100 \\
\hline
\end{tabular}

Pada Tabel 8 dilihat bahwa petani lebih menggunakan pola jarak tanam segi empat yaitu $70 \%$ karena pola jarak tanam segi empat mempunyai jumlah populasi lebih banyak. Dibandingkan dengan pola tanam segi tiga sama sisi yang mempunyai kelebihan yaitu peluang mendapatkan produktivitas lebih besar disamping itu pola segitiga sama sisi lebih efektif dalam menerima sinar matahari terhadap pertumbuhan tanaman, pola jarak tanam segitiga sama sisi memiliki populasi tanaman $15 \%$ lebih tinggi sehingga secara teoritis akan mempengaruhi produktivitas (Harahap 2006).

\section{Perawatan Tanaman}

Berdasarkan perawatan tanaman terhadap petani sampel meliputi penyulaman, penanaman tanaman penutup tanah (Cover Crop), pengendalian gulma, penunasan dan pemupukan.

\section{Penyulaman}

Penyulaman tanaman dilakukan apabila tanaman terkena serangan hama atau penyakit dan pertumbuhan tanaman tidak sempurna, untuk mengurangi dampak tersebut petani melakukan pengolahan lahan yang baik, menggunakan bibit bervarietas unggul serta pemindahan umur bibit tanam secara tepat.

Tabel 9. Distribusi Petani Sampel Berdasarkan Penyulaman Tanaman

\begin{tabular}{|c|c|c|c|c|c|c|c|}
\hline \multirow{3}{*}{ No } & \multirow{3}{*}{ Penyulaman } & \multicolumn{4}{|c|}{ Desa } & \multirow{3}{*}{$\begin{array}{l}\text { Jumlah } \\
\text { (jiwa) }\end{array}$} & \multirow{3}{*}{$\begin{array}{c}\text { Persentase } \\
(\%)\end{array}$} \\
\hline & & \multicolumn{2}{|c|}{ Pangkoh } & \multicolumn{2}{|c|}{ Mandomai } & & \\
\hline & & $\begin{array}{c}\text { Jumlah } \\
\text { (jiwa) }\end{array}$ & $\begin{array}{c}\text { Persentase } \\
(\%)\end{array}$ & $\begin{array}{c}\text { Jumlah } \\
\text { (jiwa) }\end{array}$ & $\begin{array}{c}\text { Persentase } \\
(\%)\end{array}$ & & \\
\hline 1 & Ada & 11 & 36,67 & 5 & 16,67 & 16 & 26,67 \\
\hline \multirow[t]{2}{*}{2} & Tidak & 19 & 63,33 & 25 & 85,33 & 44 & 73,33 \\
\hline & Jumlah & 30 & 100 & 30 & 100 & 60 & 100 \\
\hline
\end{tabular}

Menurut Risza (2004) selama masa TBM sebaiknya dilakukan penyulaman yang intensif agar pertumbuhan tanaman di areal pertanaman seragam (homogen). Apabila penyulaman yang dilakukan terlambat yakni setelah tanaman berumur 3 tahun akan menyebabkan perbedaan umur yang terlalu jauh dengan tanaman sebelumnya dan akan menimbulkan kesulitan dalam pemeliharaan serta akan berpengaruh terhadap proses pemanenan.

\section{Penanaman Tanaman Penutup Tanah}

Tanaman penutup tanah berfungsi sebagai menahan serta mengurangi laju jatuhnya air hujan diatas permukaan tanah, menambah bahan organik tanah, mempertahankan kelembapan tanah. Tanaman penutup tanah 
dari jenis kacang-kacangan dimaksudkan dapat menekan pertumbuhan gulma, berfungsi menghasilkan bahan organik dan unsur Nitrogen hasil fiksasi $\mathrm{N}_{2}$ dari udara.

Tabel 10. Distribusi Petani Sampel Berdasarkan Tanaman Penutup Tanah

\begin{tabular}{|c|c|c|c|c|c|c|c|}
\hline \multirow{3}{*}{ No } & \multirow{3}{*}{$\begin{array}{l}\text { Penanaman } \\
\text { Cover Crop }\end{array}$} & \multicolumn{4}{|c|}{ Desa } & \multirow{3}{*}{$\begin{array}{l}\text { Jumlah } \\
\text { (jiwa) }\end{array}$} & \multirow{3}{*}{$\begin{array}{c}\text { Persentase } \\
(\%)\end{array}$} \\
\hline & & \multicolumn{2}{|c|}{ Pangkoh } & \multicolumn{2}{|c|}{ Mandomai } & & \\
\hline & & $\begin{array}{l}\text { Jumlah } \\
\text { (jiwa) }\end{array}$ & $\begin{array}{c}\text { Persentase } \\
(\%)\end{array}$ & $\begin{array}{l}\text { Jumlah } \\
\text { (jiwa) }\end{array}$ & $\begin{array}{c}\text { Persentase } \\
(\%)\end{array}$ & & \\
\hline 1 & Ada & 3 & 10,00 & 5 & 16,67 & 8 & 13,44 \\
\hline 2 & Tidak & 27 & 90,00 & 25 & 83,33 & 52 & 86,67 \\
\hline & Jumlah & 30 & 100 & 30 & 100 & 60 & 100 \\
\hline
\end{tabular}

Banyaknya petani sampel yang tidak menggunakan tanaman penutup tanah $86,67 \%$ dari kedua desa disebabkan kurangnya biaya petani dalam memproleh tanaman penutup tanah tersebut dan sulitnya sumber penyediaan benih cover crop. Jenis tanaman penutup tanah yang umum digunakan dalam perkebunan kelapa sawit yaitu Mucuna cochinchinensis, Psophocarphus palustries, Centrocema pubescens, Pueraria phseoloides, Pueraria javanica, Calopogonium caeruleum, Calopogonium mucunoides (Pahan, 2012).

\section{Pengendalian gulma}

Pertumbuhan gulma pada perkebunan kelapa sawit tidak dikehendaki karena dapat mengakibatkan penurunan produksi, menurunkan suatu produksi mengeluarkan senyawa alelopati yang mengganggu pertumbuhan kelapa sawit, menjadi inang bagi hama, mengganggu tata air dan meningkatkan biaya usaha tani (Pahan 2008).

Tabel 11. Distribusi petani sampel berdasarkan teknik pengendalian gulma

\begin{tabular}{|c|c|c|c|c|c|c|c|}
\hline \multirow{3}{*}{ No } & \multirow{3}{*}{$\begin{array}{l}\text { Cara } \\
\text { Pengendalian }\end{array}$} & \multicolumn{4}{|c|}{ Desa } & \multirow{3}{*}{$\begin{array}{l}\text { Jumlah } \\
\text { (jiwa) }\end{array}$} & \multirow{3}{*}{$\begin{array}{c}\text { Persentase } \\
(\%)\end{array}$} \\
\hline & & \multicolumn{2}{|c|}{ Pangkoh } & \multicolumn{2}{|c|}{ Mandomai } & & \\
\hline & & $\begin{array}{c}\text { Jumlah } \\
\text { (jiwa) }\end{array}$ & $\begin{array}{c}\text { Persentase } \\
(\%)\end{array}$ & $\begin{array}{c}\text { Jumlah } \\
\text { (jiwa) }\end{array}$ & $\begin{array}{c}\text { Persentase } \\
(\%)\end{array}$ & & \\
\hline 1 & Kimia & 16 & 53,33 & 22 & 73,33 & 38 & 63,33 \\
\hline 2 & Mekanis & 14 & 46,67 & 8 & 26,67 & 22 & 36,67 \\
\hline & Jumlah & 30 & 100 & 30 & 100 & 60 & 100 \\
\hline
\end{tabular}

Pelaksanaan kegiatan dilakukan dengan membabat gulma disekeliling piringan dengan jarak 1,5 m dari pokok tanaman. Tabel 11 dilihat bahwa mayoritas petani sampel melakukan pengendalian gulma menggunakan teknik kimiawi yaitu mencapai 63,33\%. Dalam kaitan ini petani petani melakukan kegiatan penyemprotan 3 kali dalam satu tahun. Untuk pengendalian secara manual dengan persentase 36,67\% petani melakukan kegiatan sebanyak empat kali dalam setahun, dalam hal tersebut pengendalian secara manual kurang efektif sebanyak empat kali setahun jika pengendalian tidak dilakukan secara mekanis dan kimia.

\section{Penunasan}

Hasil pengamatan sistem penunasan di kebun swadaya dapat dilihat pada tabel 12 .

Tabel 12. Distribusi petani sampel berdasarkan sistem penunasan

\begin{tabular}{|c|c|c|c|c|c|c|c|}
\hline \multirow{3}{*}{ No } & \multirow{3}{*}{$\begin{array}{l}\text { Frekuensi } \\
\text { Penunasan }\end{array}$} & \multicolumn{4}{|c|}{ Desa } & \multirow{3}{*}{$\begin{array}{l}\text { Jumlah } \\
\text { (jiwa) }\end{array}$} & \multirow{3}{*}{$\begin{array}{c}\text { Persentase } \\
(\%)\end{array}$} \\
\hline & & \multicolumn{2}{|c|}{ Pangkoh } & \multicolumn{2}{|c|}{ Mandomai } & & \\
\hline & & $\begin{array}{c}\text { Jumlah } \\
\text { (jiwa) }\end{array}$ & $\begin{array}{c}\text { Persentase } \\
(\%)\end{array}$ & $\begin{array}{c}\text { Jumlah } \\
\text { (jiwa) }\end{array}$ & $\begin{array}{c}\text { Persentase } \\
(\%)\end{array}$ & & \\
\hline 1 & $1 \mathrm{x} /$ tahun & 7 & 23,33 & 4 & 13,33 & 11 & 18,33 \\
\hline 2 & 2x/tahun & 23 & 76,67 & 26 & 86,67 & 49 & 81,67 \\
\hline \multirow[t]{2}{*}{3} & $3 x /$ tahun & - & - & - & - & - & - \\
\hline & Jumlah & 30 & 100 & 30 & 100 & 60 & 100 \\
\hline
\end{tabular}

Menurut Wawan (2003), penunasan bertujuan untuk menjaga keseimbangan pertumbuhan vegetatif dan generatif, mempermudah pelaksanaan panen, mengurangi salah satu faktor yang menghalangi penyerbukan secara alami, cahaya dapat masuk lebih merata sehingga proses asimilasi dan sirkulasi udara dapat lebih baik, mendorong penyaluran zat hara yang diserap tanaman pada daun yang lebih produktif dan mengurangi brondolan yang menyangkut pada pelepah. 
Menurut Wawan (2003), penunasan bertujuan untuk menjaga keseimbangan pertumbuhan vegetatif dan generatif, mempermudah pelaksanaan panen, mengurangi salah satu faktor yang menghalangi penyerbukan secara alami, cahaya dapat masuk lebih merata sehingga proses asimilasi dan sirkulasi udara dapat lebih baik, mendorong penyaluran zat hara yang diserap tanaman pada daun yang lebih produktif dan mengurangi brondolan yang menyangkut pada pelepah.

\section{Pemupukan}

Pemupukan pada tanaman kelapa sawit dilakukan untuk memenuhi kebutuhan tanaman terhadap unsur hara. Pemupukan menunjang pertumbuhan tanaman kelapa sawit yang sehat dan untuk mencapai produksi buah yang optimal serta tanaman kelapa sawit tahan terhadap hama dan penyakit.

Keberhasilan pemupukan meliputi manajemen pemupukan yang baik, rekomendasi pemupukan yang diberikan oleh lembaga penelitian selalu menggunakan konsep tepat jenis, tepat dosis, frekuensi, kualitas dan cara pemupukan. Hasil distribusi petani sampel berdasarkan jenis pemupukan dilihat pada Tabel 13.

Pada Tabel 13 dapat dilihat bahwa untuk jenis dan dosis pupuk yang digunakan petani kedua Desa pada penggunaan pupuk Urea, $\mathrm{KCl}$, dan TSP lebih dominan, sedangkan pupuk Kiesrit dan Borate sangat dibutuhkan oleh tanaman. Untuk itu pemupukan tersebut merupakan unsur hara sekunder dalam melengkapi kebutuhan akan unsur hara pada tanaman kelapa sawit, apabila unsur hara makro tidak tercukupi bagi tanaman serta pertumbuhan dan produktivitas belum optimum.

Tabel 13. Distribusi Petani Sampel Berdasarkan Jenis Pemupukan

\begin{tabular}{llcccc}
\hline & & \multicolumn{2}{c}{ Desa } \\
\cline { 3 - 6 } No & Jenis Pupuk & \multicolumn{2}{c}{$\begin{array}{c}\text { Pangkoh } \\
(\mathrm{kg} / \text { pokok/tahun) }\end{array}$} & \multicolumn{2}{c}{$\begin{array}{c}\text { Mandomai } \\
\text { (kg/pokok/tahun) }\end{array}$} \\
\cline { 3 - 6 } & & Jumlah & Rata-rata & Jumlah & Rata-rata \\
\hline 1 & Urea & 16,8 & 0,56 & 12,5 & 0,41 \\
2 & KCl & 18,3 & 0,61 & 10,0 & 0,33 \\
3 & TSP & 19,5 & 0,65 & 13,0 & 0,43 \\
4 & Kieserit & 6,0 & 0,20 & 5,4 & 0,18 \\
5 & Borate & 1,8 & 0,06 & 0,3 & 0,01 \\
\hline
\end{tabular}

Menurut Sunarko (2014) menyatakan bahwa penggunaan berupa pupuk Kieserite $26 \% \mathrm{MgO}$ dan pupuk HGF-Borate $46 \% \mathrm{~B}_{2} \mathrm{O}_{5}$, sifat dan interaksi antagonis antar pupuk dapat terjadi karena pemasukan ion atau unsur lain kedalam sel tanaman. Adapun waktu yang terbaik untuk melakukan pemupukan yaitu pada saat musim penghujan, keadaan tanah masih dalam kondisi sangat lembab dan tidak tergenang oleh air.

\section{Produktivitas}

Pemupukan merupakan salah satu bagian penting dari tahapan teknis budidaya tanaman kelapa sawit dengan tujuan sebagai salah satu cara untuk memenuhi kebutuhan tanaman akan unsur hara baik unsur hara makro maupun unsur hara mikro agar tercapainya produktivitas tanaman yang optimal. Kondisi lahan dan iklim yang sesuai untuk tanaman kelapa sawit akan dapat mengoptimalkan pertumbuhan dan perkembangan tanaman kelapa sawit. Berikut ini data produktivitas tanaman kelapa sawit petani swadaya pada Tabel 14.

Tabel 14. Distribusi petani sampel berdasarkan produksi kelapa sawit

\begin{tabular}{|c|c|c|c|c|c|}
\hline \multirow{2}{*}{ No } & \multirow{2}{*}{$\begin{array}{l}\text { Luas } \\
\text { Lahan } \\
\text { (ha) }\end{array}$} & \multirow{2}{*}{$\begin{array}{l}\text { Umur } \\
\text { Tanaman } \\
\text { (tahun) }\end{array}$} & \multicolumn{2}{|c|}{$\begin{array}{c}\text { Produksi Kelapa Sawit Swadaya } \\
\text { (kg/ha/tahun) }\end{array}$} & \multirow{2}{*}{$\begin{array}{c}\text { Produksi Berdasarkan } \\
\text { PPKS Medan } \\
\text { (kg/ha/tahun) } \\
\text { Pada KKL S2 }\end{array}$} \\
\hline & & & $\begin{array}{c}\text { Rawangkao } \\
\text { (rata-rata) }\end{array}$ & $\begin{array}{l}\text { Lubuk Dalam } \\
\text { (rata-rata) }\end{array}$ & \\
\hline 1 & 2 & 3 & 8,089 & 7,344 & 13,550 \\
\hline 2 & 3 & 4 & 9,980 & 9,911 & 16,000 \\
\hline 3 & 4 & 5 & 11,100 & 10,011 & 18,500 \\
\hline 4 & 5 & 6 & 11,084 & 11,807 & 23,000 \\
\hline
\end{tabular}

Produksi kelapa sawit dapat ditingkatkan dengan memperbaiki teknik budidaya kelapa sawit dengan prosedur yang ditetapkan. Menurut Pusat Penelitian Kelapa Sawit (2003), persilangan D x P mempunyai keunggulan tersendiri yang berpotensi menghasilkan TBS sebesar 32-39 ton/ha/tahun. Produktivitas tanaman kelapa sawit dipengaruhi oleh beberapa faktor teknis budidaya maupun kondisi lahan dan iklim.

Selain perawatan tanaman ketersediaan air yang kurang dalam jangka waktu lama, dapat mengakibatkan kekeringan, kerusakan vegetatif tanaman yaitu terhambatnya pembukaan daun muda dan berpengaruh terhadap pembentukan bakal bunga serta menurunnya produksi TBS (Hazriani, 2004). 


\section{KESIMPULAN DAN SARAN}

\section{Kesimpulan}

1. Aspek budidaya tanaman kelapa sawit petani swadaya dipengaruhi oleh karakteristik internal yang berkaitan dengan keperibadian petani seperti tingkat pendidikan SD 50,00\%, jumlah tanggungan keluarga 4-6 jiwa $66,67 \%$, kelompok umur $\geq 25-5551,66 \%$ dan pengalaman berusaha tani 5-8 tahun 66,67\%.

2. Teknik budidaya tanaman kelapa sawit yang dilakukan oleh petani di Kabupaten Pulang Pisau pada Desa Pangkoh dan Mandomai belum mengikuti anjuran PPKS Palangka Raya. Sebab 68,34\% petani sampel menggunakan bibit yang diketahui jenisnya, 26,67\% menggunakan umur bibit 12-14 bulan, 43,33\% petani sampel yang menggunakan jarak tanam sesuai anjuran, $30 \%$. Menggunakan pola jarak tanam segitiga sama sisi, $25 \%$ yang menggunakan ukuran lubang tanam $60 \mathrm{~cm} \times 60 \mathrm{~cm} \times 60 \mathrm{~cm}$, yang melakukan penyulaman $26,67 \%$, penanaman tanaman penutup tanah $13,44 \%$, penunasan 2 kali per tahun $81,67 \%$, $0 \%$ dalam dosis pemupukan dan $63,33 \%$ pengendalian gulma secara kimia. Sehingga dirata-ratakan 37,8\% petani sampel yang melakukan teknik budidaya tanaman kelapa sawit sesuai dengan anjuran PPKS Medan.

\section{Saran}

Petani swadaya diharapkan mengikuti anjuran PPKS Palangka Raya mengenai budidaya tanaman kelapa sawit sesuai prosedur, secara prinsip pribadi maupun kelompok dengan didampingi oleh penyuluh lapangan. Pemerintah dan dinas perkebunan harus ikut andil dalam memperhatikan teknik budidaya tanaman kelapa sawit yang dilaksanakan secara swadaya di Kabupaten Pulang Pisau pada khususnya.

\section{DAFTAR PUSTAKA}

Badan Pusat Statistik Provinsi Riau. 2021. Kalimatan Tengah Dalam Angka 2021. Palangka Raya.

Badan Pelaksana Penyuluhan dan Ketahanan Pangan. 2021. Laporan Penggunaan Lahan Pertanian Dan Bukan Pertanian. Badan pelaksana penyuluhan dan ketahanan pangan Kabupaten Pulang Pisau. Pulang Pisau.

Edwina, S. 2004. Distribusi Pendapatan Petani Kelapa Sawit Pola Plasma dan Pola Swadaya di Kecamatan Pangkalan Kuras, Kabupaten Pelalawan. Agriculture Science and Technology Journal, Fakultas Pertanian Universitas Riau. Vol.3:2.

Edwina, S., Adiwirman, F. Puspita, dan G.M.E. Manurung. 2012. Karakteristik dan tingkat pengetahuan petani kelapa sawit rakyat tentang pemupukan di Kecamatan Tanah Putih Kabupaten Rokan Hilir. Indonesian Journal of Agricultural Economics (IJAE). Vol. 3:163- 176.

Fauzi, Y., I. Widiastuti, Setyawibawa dan R. Hartono. 2008. Kelapa Sawit. Penebar Swadaya. Jakarta.

Harahap, Y., Winarna dan E.S. Sutarta. 2005. Produktivitas Tanaman Kelapa Sawit. Tinjauan dari Aspek Tanah dan Iklim. Dalam W. Darmosakoro, E.S. Sutarta dan Winarna (Eds). Lahan dan Pemupukan Kelapa Sawit. Medan.

Harahap, I.Y. 2006. Penataan Ruang Pertanaman Kelapa Sawit Berdasar Pada Konsep Optimalisai Pemanfaatan Cahaya Matahari. Warta PPKS. Medan. Vol.14 (1): 9-5.

Hakim, M. 2007. Kelapa Sawit: Teknis Agronomis dan Manajemennya (Tinjauan Teoritis dan Praktis). Lembaga Pupuk Indonesia. Jakarta. 296 hal.

Hernanto, F. 1995. Ilmu Usaha Tani. Penerbit Penebar Swadaya. Jakarta.

Hazriani, R. 2004. Hubungan antara ketersediaan air tanah dengan produksi tandan buah kelapa sawit di Area PT. Sinar Dinamika Kapuas I Kabupaten Sintang. Tesis. Program Pascasarjana IPB. Bogor.

Pusat Penelitian Kelapa Sawit 2003. Budidaya Kelapa Sawit. Modul M 100-203. Medan.

Pahan, I. 2005. Pola peremajaan areal plasma dari segi pembinaan petani, ketersediaan modal dan mengatasi kesenjangan pendapatan. Prosiding Seminar Nasional Perkebunan Kelapa Sawit Rakyat; Pemberdayaan Perkebunan Kelapa Sawit Rakyat sebagai Upaya Penguatan Ekonomi Kerakyatan. Pekanbaru, 15-16 April 2005.

2008. Panduan Lengkap Kelapa Sawit. Penebar Swadaya. Jakarta.

2012. Kelapa Sawit: Manajemen Agribisnis dari Hulu Hingga Hilir. Penebar Swadaya. Jakarta. 412 hal.

Risza, S. 2004. Upaya Peningkatan Produktivitas Kelapa Sawit. Kanisius. Yogyakarta. 188 hal. 
Sunarko. 2014. Budidaya Kelapa Sawit di Berbagai Jenis Lahan. Agromedia. Jakarta. 200 hal.

Soekartawi. 1993. Prinsip Dasar Ekonomi Pertanian, Teori dan Aplikasi. Rajawali Pers. Jakarta.

Setyamidjaja, D. 2006. Kelapa Sawit: Teknik Budidaya, Panen, dan Pengolahan. Kanisius. Yogyakarta. 127 hal.

Wawan. 2003. Pengelolaan perkebunan kelapa sawit (Elaeis guineensis Jacq.) dengan aspek khusus pemanenan di kebun serbangan. PT. Bakrie Sumatera Plantation Tbk., Sumatera Utara. 